\title{
Economic performance of agritourism: an analysis of farms located in a less favoured area in Italy
}

\author{
Brunella Arru, Roberto Furesi, Fabio A. Madau* (D) and Pietro Pulina
}

\author{
* Correspondence: famadau@uniss.it \\ Department of Agricultural \\ Sciences, University of Sassari, Viale \\ Italia 39/a, 07100 Sassari, Italy
}

\begin{abstract}
Farms that operate in less favoured areas (LFAs) often suffer in achieving adequate profits. Diversification strategies, such as direct selling and offering recreational services, can play an important role in integrating earning sources and, as a consequence, increasing farm profitability. Such opportunities would depend on the efficient distribution and use of farm resources among different activities as well as the added value creation of farm output. However, achieving positive results is not obvious in LFAs due to different types of inherent constraints (geographical, social, economic). The paper aims to evaluate the role of agritourism in affecting the economic performance of multifunctional farms located in a less favoured area of Sardinia (Italy). To be more precise, using so-called working farm income as the main indicator resulting from balance sheet analysis, production factor rewards are determined for 15 agritourism farms. The results show controversial performance but basically highlight the difficulty agritourist farmers have both remunerating their work at market price levels and being profitable. This research contributes to the debate on LFAs and offers useful reflections for policy-makers and practitioners about the potential and critical aspects of agritourism in LFAs.
\end{abstract}

Keywords: Balance sheet analysis, Multifunctionality, Working farm income, Agritourism

\section{Introduction}

The areas facing natural or other specific constraints (ANCs) in the past referred to as "less favoured areas (LFAs)" are territories characterised by different types of handicaps (geographical, social, economic) that limit development perspectives. According to the Council of the European Union (EU), LFAs can be classified into three categories: (a) mountain areas, which suffer from a short crop season due to high altitude and/or steep slopes; (b) areas facing significant natural constraints; and (c) areas affected by specific constraints (Council of the European Union 2013 Regulation No 1305/2013, art. 32).

Among others, these constraints threaten agricultural land use persistence in LFAs because of low factor productivity and income opportunities (European Commission

(c) The Author(s). 2021 Open Access This article is licensed under a Creative Commons Attribution 4.0 International License, which permits use, sharing, adaptation, distribution and reproduction in any medium or format, as long as you give appropriate credit to the original author(s) and the source, provide a link to the Creative Commons licence, and indicate if changes were made. The images or other third party material in this article are included in the article's Creative Commons licence, unless indicated otherwise in a credit line to the material. If material is not included in the article's Creative Commons licence and your intended use is not permitted by statutory regulation or exceeds the permitted use, you will need to obtain permission directly from the copyright holder. To view a copy of this licence, visit http://creativecommons.org/licenses/by/4.0/. 
2017). On the other hand, LFAs play an essential role in maintaining highly valuable landscapes and preserving biodiversity and rural cultural heritage, making high-quality food production and working opportunities actually possible (Cooper et al. 2006). Farmers continue to operate in these areas based on these factors. Moreover, the lifestyle motive, social, and cultural contexts and traditions, and the expectation of future land values are important, too (Cooper et al. 2006). Least of all, so-called socioemotional well-being, i.e. emotional attachment to the business, improves family wealth, stemming from the fact that family members work in the same business (Gomez-Mejia et al. 2011). In such circumstances, family and small-size farms-the main farming models in the EU-play a crucial role in the socio-economic and environmentally sustainable development of rural communities and the promotion of a healthy lifestyle in LFAs (European Commission 2013; Toader and Roman 2015).

Previous studies have shown that lifestyle and market-oriented goals can coexist (Bredvold and Skålén 2016). This means that farmers' socio-emotional well-being and affection for land and traditional values cannot neglect the capacity to reward family members' work. On the other hand, farms have to remain socially and economically viable in the long term. Since 1992, the EU Rural Development Policy (RDP) has supported such coexistence by ensuring a compensatory payment for farmers that operate in LFAs. Furthermore, small and disadvantaged farms are recovered by RDP by a broad range of measures (e.g., aid for capital investments, support for increasing market orientation) in order to reinforce their income and reduce the gap that would hinder their viability and sustainability. However, the main EU effort is aimed at promoting farm diversification by expanding possible income sources. The underlying rationale is that diversification is one of the most effective strategies for income stabilization and enhancement, especially for small and disadvantaged farms (Marsden et al. 1989; Ilbery 1991; Bateman and Ray 1994; Johnsen 2004; Vik and McElwee 2011).

Farm diversification triggers broad processes with reference to core activities in reaction to external pressures, aiming to maintain the business and improve economic performance (De Rosa et al. 2019). The transition towards multifunctional and pluriactive agriculture is key to safeguarding farm profitability. It develops through three paths (Henke et al. 2014): agricultural diversification (planting new and alternative crops, often combined with the use of marketing strategies focused on niche markets and direct selling), income diversification (re-locating farm resources to off-farm activities), and structural diversification (starting new on-farm activities) (Ilbery 1991; Bowler 1992; Markelova et al. 2009; Fischer and Qaim 2012).

Among new on-farm activities, agritourism, considered a subset of rural tourism (Phillip et al. 2010), is an internal income diversification strategy that emerges from a lack of off-farm income opportunities and a desire to balance the agricultural income (Streifeneder 2016). Agritourism is one of the most relevant and innovative diversification processes in agriculture. It has dramatically increased in Europe and throughout the world in the last 30 years (Nickerson et al. 2001; Meert et al. 2005; Knowd 2006; McGehee 2007; Sznajder et al. 2009; Arroyo et al. 2013; Vogt 2013; Fagioli et al. 2014; Schilling et al. 2014). Among the many contributions to the scientific debate about the definition of agritourism activity (Phillip et al. 2010; Flanigan et al. 2014; Streifeneder 2016; Broccardo et al. 2017; Liu et al., 2017) and different national and regional public laws and regulations, it is possible to identify a common feature, which is the offering 
of recreational services by farms. Broadly speaking, agritourism is a style of holiday that is spent on a farm (Sznajder et al. 2009). The diversification and generation of additional income through touristic on-farm activities mainly concerns two tourist services (Arru et al. 2019): preparing and serving meals mainly made from farm and/or local products, and providing overnight accommodation.

Agritourism is "linked to internal and external push-and-pull factors within the framework of agro-structural change and rural area development" (Streifeneder 2016, p. 251). Indeed, this sort of diversification, on the one hand, can capture the increasing and segmented tourist demand, guaranteeing a further income source for farmers (Tew and Barbieri 2012; Schilling et al. 2014, 2016; Arru et al. 2019).

On the other hand, from a multifunctional perspective, the recreational function allows farmers to promote sustainability, incentivises good farming practices, and has positive implications in terms of rural territory development (Tew and Barbieri 2012; Mastronardi et al. 2015; Flanigan et al. 2015). In particular, agritourism farms implement strategies oriented towards finding job opportunities for farm family members.

The characteristic phases of agritourism development are described by Arnold and Staudacher's (Arnold and Staudacher 1981) theoretical model, which involves a prephase and three main stages. In the pre-phase, one can observe limited involvement of the farmer, who is reluctant to spend time away from the main activity and therefore devotes few resources to investing in building and infrastructure renovation in order to dedicate them to reception activities. Later, the farmer starts offering overnight and meal services but does not reduce the work effort devoted to agricultural activities in favour of agritourism, still conceived as a mere additional activity that could generate work overload. That is why the earlier kind of agritourism activity was the basic kind of bed-and-breakfast service. In the second phase, the farmer enlarges his capacity by increasing the number of rooms and tables in order to increase the income to be reinvested within the company. Finally, intensification of the agritourism activity pushes the farmer to divert attention from core agricultural activities and devote a larger part of his work to recreational services. This gradual development allows him to increase income coming from different sources of his multifunctional business (Bellencin-Meneghel 1991).

It is important to emphasise that the life cycle of an agritourism would be closely linked to the life cycle phase of the tourist destination in which it is located (Petrovic et al. 2016). According to Butler (1980), the tourist destination life cycle consists of six main phases. The first phase (research) is characterised by infrastructure or superstructure scarcity, and by allocentric tourists. The latter, according to Plog (1974), are curious, adventurous and prone to new discoveries, they love destination unspoilt by tourism and are drawn by natural resources, historical and cultural heritage, turn to unstandardised structure, and ask for minimal comforts. In the second phase, the involvement, the number of tourists (who become more "near-allocentric", i.e. less extreme in terms of commitment towards new experience not see everything to be familiar) increases considerably inasmuch are attracted by a rural destination that is new and still not established. The seasonal tourist movement prevails, and its impact usually leads the public sector to be involved in tourism development in the destination, whereas the private sector is involved in the enrichment of material basis. The development phase sees growth and differentiation of supply, where local enterprises 
progressively lose control to national and foreign enterprises. The consolidation phase is characterised by the mass tourism that becomes the most important local economic sector, although its growth rate flows begins to slow. In the stagnation stage, tourist numbers have reached their peak, the destination's image has been well-established but is no longer fashionable. Finally, the post-stagnation stage can present the scenario of stabilisation, rejuvenation, or decline.

On the other hand, some normative constraints limit the expansion of agritourism as a farm activity. In Italy, for example, the income generated or the labour spent with reference to agritourism and to "activities related to agriculture" cannot be higher than those of the main farm activity, i.e. the production of food/feed/energy goods (the choice of the prevalence criterion is made by the farmer). This prevalence constraint in favour of agriculture implies that agritourism can increase the farm's turnover, but it cannot overcome its weight with respect to the main agricultural activities.

All these arguments considered, this paper aims to evaluate the economic performance derived from agritourism farms located in an LFA of Sardinia (Italy), the geographical region of Montiferru. The study explores the ability of farms that offer recreational services to be actually profitable, with specific reference to their development phase. In more detail, using balance sheet analysis according to Serpieri's model (1950), this paper aims to answer the following question: are agritourism farms located in an LFA like the Montiferru region capable of adequately rewarding the work of family members?

Some studies have been published on the role of agritourism and/or of specific agritourist activities in specific contexts such as mountain farming. Recently, Stotten et al. (2019) investigated on the impact of more types of accommodation supplied by farmers on the preservation of the farm in the Ötztal valley in Austria. However, excluding the mountain areas sensu scricto, to the best of our knowledge, this paper is the first to explicitly study agritourism as a response to the income problems of family farms in LFAs.

The work is structured as follows. Section 2 illustrates the peculiarities of the area, the characteristics of the farms and the research methodology. Section 3 presents the research results. The last section concludes the paper, draws implications for practice, policy-making and academia, and suggests avenues for further work.

\section{Materials and methods}

\section{Study area, choice of farms and data collection}

The region of Montiferru is geographically located in the middle-west of the island of Sardinia. According to European Commission (2017), it is an area in total danger of abandonment of land use. In effect, the presence of a multiplicity of negative factors of an economic, environmental and settlement nature have jointly contributed to determining its low level of development. It is a hilly region that covers $487 \mathrm{~km}^{2}$, with a population density (close to 24 inhabitants per square kilometre) significantly lower than the national average (Istat 2019). The morphological and environmental characteristics of the Montiferru territory have dictated the shape of the local agricultural economy (Arru et al. 2019). As typically observed in Sardinian hilly and mountain areas, the leading practice is sheep breeding, and most of the arable land is therefore covered by 
grazing. Sheep are bred for milk production, which is almost totally processed by the local dairy industry (Furesi et al. 2013; Camanzi et al. 2018), where the meat from lambs has to be considered a conjoint output. Sheep grazing is quite exclusively carried out following extensive or semi-extensive management rules. Furthermore, horticulture, olives and grapes are widespread in Montiferru.

In the last decades, the number of agritourism businesses has increased considerably in Montiferru (Arru et al. 2019), and this characteristic makes the region particularly worthy of being taken as a reference case in this study. The increased farm diversification and tourism services, basically meals and overnight stays as on-farm activities, arises from the actions of 2 main categories of factors.

First, the Sardinian RDP has promoted the creation of a virtuous local action group (LAG) in the region. Driven by the strategic mission of making the productive local system competitive, the LAG has initiated actions aimed at encouraging and fostering valorisation paths and supporting traditional and identity food production. Among the supported activities, agritourism has emerged as one of the main diversification tools developed by farmers to promote local production, culture and tradition.

Second, recurrent crises of agricultural markets push farmers to search for opportunities to integrate low and volatile agricultural income. An attractive opportunity has been identified in the growing demand for food and wine tourism in this area (e.g. Malvasia and Vernaccia local wines), which has also been leveraged to make the entire environmental and cultural heritage of the region known, further shifting the seasonal tourist flow from the coasts to the hinterland, such as Montiferru. Although Montiferru is less known by tourists than other Sardinian regions, it is starting to benefit from rural tourism, and it has become an appreciated destination in the last two decades. The development of tourism and the increasing interest in food and wine routes have promoted farm diversification, and have led to agritourism being considered as an opportunity to diversify income sources.

Based on these findings (local residents involved in tourism, emergence of secondary tourism facilities such as agritourism, tourism season development, greater policy involvement, increase in marketing and promotion activities), Montiferru is currently in the involved stage. Therefore, given its condition of LFA and its phase in the Tourist Area Evolution (Butler 1980), the Montiferru region analysis appears useful in understanding a possible evolution path of a LFA as well as which private and policy actions should be done to increase the income of farms and the rural-area employment. Drawing on the data provided by the Regional Agricultural Extension Service Agency (LAORE), a total of 18 agritourism businesses operating in the Montiferru region were selected. Most were founded in the last decade; therefore, they operate in the early phases of (Arnold and Staudacher 1981) life-cycle model. This means that agritourism is often far from the maturity stage. This is a crucial point in assessing the economic performance of farms and the ability of agritourism to positively affect incomes today.

A sample of 15 farmers agreed to provide economic information about their agricultural and recreational services activities. The data were collected in 2017 by direct interviewers with the farmers. The main characteristics of the sample are reported in Table 1.

The farms are all family-run; except for 2 of them, they are still run by the founder. Twelve of the 15 farms have a relatively small utilised agricultural area, while 9 
Table 1 Sample overview

\begin{tabular}{|c|c|c|c|c|c|c|c|c|c|c|c|c|c|c|c|}
\hline Items/farms & 1 & 2 & 3 & 4 & 5 & 6 & 7 & 8 & 9 & 10 & 11 & 12 & 13 & 14 & 15 \\
\hline Age of farm (year) & 60 & 35 & 24 & 6 & 17 & 14 & 67 & 17 & 35 & 4 & 15 & 2 & 37 & 22 & 11 \\
\hline Age of agritourism (year) & 3 & 16 & 5 & 1 & n.d. & n.d. & 10 & n.d. & 2 & 1 & 15 & 2 & n.d. & 10 & n.d. \\
\hline $\begin{array}{l}\text { Phases of Arnold and Staudacher's } \\
\text { model }\end{array}$ & 3 & 3 & 3 & 3 & 2 & 2 & 2 & 1 & 1 & 1 & 1 & 1 & 1 & 1 & 1 \\
\hline Land (ha) & 72 & 60 & 10 & 9 & 80 & 100 & 70 & 140 & 60 & 3 & 36 & 195 & 60 & 45 & 21.5 \\
\hline \multicolumn{16}{|c|}{ Family workers (full-time equivalent units) } \\
\hline Agriculture & 3 & 2 & 1.5 & 2 & 1 & 3 & 3 & 5 & 2 & 2 & 3 & 3 & 1 & 2 & 1 \\
\hline Agritourism & 2 & 2 & 1.5 & 2 & 1 & 2 & 3 & 5 & 2 & 1 & 2 & 1 & 2 & 1 & 1 \\
\hline Specialization & $d$ & a & $b$ & $c$ & a & a & e & a & a & f & c & a & c & $b$ & $b$ \\
\hline Restaurant & $x$ & $x$ & $x$ & $x$ & $x$ & $x$ & $x$ & $x$ & $x$ & $x$ & $x$ & $x$ & $x$ & & \\
\hline Overnight stay & $x$ & $x$ & & $x$ & $x$ & & $x$ & $x$ & $x$ & $x$ & $x$ & & $x$ & $x$ & \\
\hline Others activities & & h & & $g$ & & g & & i & & & & & & & $g$ \\
\hline 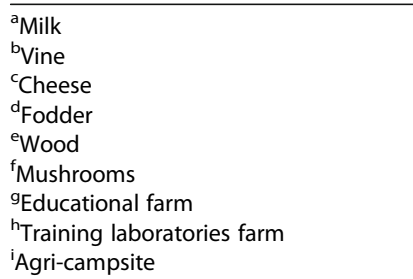 & & & & & & & & & & & & & & & \\
\hline
\end{tabular}

specialise in milk production and processing. Fourteen farms manage livestock production, primarily cattle, sheep and swine.

Agritourism activities have been integrated in recent years (5 farms in the last 4 years). Thirteen farms offer restaurant services. Almost all farms carry out this activity throughout the year, even if on request and with the bulk of services during the spring and summer months. The number of seats is contained in a wide range from a minimum of 30 to a maximum of 250. Eleven farms offer accommodations, with an average of 15 rooms. Among these, only one does not provide this service for the whole year. Moreover, 4 farms expanded their practice to include an educational farm, while 2 others include tastings and agri-campsites.

\section{Methodological approach}

An estimation of the farms' economic performance was carried out by applying balance sheet analysis according to Serpieri (1950)'s model, which has been widely used by Italian agricultural economics scholars when investigating cost structure, profitability and other economic indicators of farms (Atzori et al. 2015). The procedure allows an analysis of farms' economic performance by considering the entire bundle of revenues and costs related to the production process.

Basically, Serpieri's model considers all relevant explicit and implicit costs. First are the costs incurred for using technical inputs, land, employers and capital endowment provided by non-farm sources. These are also called money costs (Deepashree 2013). Second are opportunity costs that occur when a farm uses internal resources without any explicit compensation for their utilisation, forgoing the ability to earn money from their use elsewhere. In broad terms, implicit costs, also called imputed costs, include the cost of factors owned by the farm and used in its production processes (Atzori et al. 2015). 
This cost distinction is important, since it allows us not only to calculate the accounting and economic profits (including actual cash payments), but also to factor in the overall economic profit (Deepashree 2013). An indicative example of implicit cost is the opportunity cost of a farmer and/or his family members of working in their own business. In fact, all the selected farms are family farms, implying that at least a part of the total work is done by the farmer and/or his family. Since an explicit cost (remuneration) is not identified for this work, and considering the farmers' behaviour in the observed area, also highlighted by the interviews, it is not unreasonable to assume that the farmers' objective is not so much to maximise profit but rather to obtain the highest level of working farm income (WFI), i.e.:

$$
\mathrm{WFI}=W i \pm P
$$

where $W i$ corresponds to the implicit wage that would remunerate the farmer for his work and $P$ is profit (or loss). In other terms, WFI is the part of income that is incumbent on the farmer both as a real entrepreneur, i.e. the one who assumes the risk of the decision, and as a worker on his farm.

Step by step, the balance sheet analysis was carried out as follows:

Gross farm revenue (GFR) is represented by:

- Value of sold agricultural products (except for meat)

- Value of produced meat expressed in term of live animal gross profit margin (LAGP)

- Value of recreational services provided

- Financial aid granted to farms

The value of agricultural products sold is easy to calculate, and it corresponds to the revenues earned from selling farm food/feed products. We handled produced meat separately from the rest of the products to solely take into account the meat produced in a given year. This occurs because a part of sold meat in the year could be previously realised, or part of the meat produced in the year could be sold subsequently. For these reasons, the average value of meat produced through the LAGP is determined as follows:

$$
\mathrm{LAGP}=\left(V s+V f i_{i}\right)-(V p+V i i)
$$

where $V s$ is the value of meat sold in a certain year, $V p$ is the value of meat purchased by farmers in a certain year, and $V f i$ and $V i i$ are the value of livestock at the end and the beginning of the year considered. The former term of the equation represents a potential revenue item (the value of meat actually sold and saleable meat) and the latter a potential cost item (the value of meat actually purchased and the cost related to initial livestock investment).

The value of recreational services provided corresponds to the revenue derived from agritourism, especially from accommodation and food service on-farm activities. Obviously, in the case of restaurant service, we avoided the risk of "double accounting" related to agricultural products both realised and served on a farm. Indeed, we did not compute in the first item (the value of sold products) the share of farm products used 
as raw input for a restaurant, and we considered the entire value of meals provided in this item.

Financial aid is basically represented by payments granted by the Common Agricultural Policy (CAP) to farmers, i.e.: (1) direct single payments to farms, (2) subsidies provided by the Sardinian RDP 2014-2020 measure for animal health and welfare, (3) RDP compensatory aid for LFAs (the entire Montiferru region is recognised as actually being an LFA), and (4) other eventual RDP measures.

On the cost side, a distinction between cost related to agriculture, cost related to agritourism and general cost was made to evaluate the weight of each activity.

The joint analysis of revenues and costs allows the determination of two main balance indicators. The first indicator calculated is the net farm revenue (NFR):

$$
\mathrm{NFR}=\mathrm{GFR}-(I v+I f+T x)
$$

where $I v$ and $I f$ are the costs for the use of variable and fixed (capital) inputs, respectively, and $T x$ is the value of taxes paid. If is calculated as depreciation charge on fixed technical inputs (basically buildings and machinery). NFR can be defined as the sum of compensation due to economic subjects that participate in the production process by providing capital, management and labour, after deducting all production expenses. NFR gives us a measure of the increase in farm income generated.

The second balance indicator is net income (NI), which represents the difference between NFR and the costs that a farmer has to support for remunerating hired labour, financial capital and land (explicit cost):

$$
\mathrm{NI}=\mathrm{NFR}-(W e+C e+L e)
$$

where $W e$ is the explicit cost for remunerating work (wages), Ce is the explicit cost related to the provision of capital and corresponds to interest, and $L e$ is the explicit cost related to the land (rent). Basically, NI represents the sum of the farmer's income due to his direct contribution to the production process in terms of capital and work as well as the entrepreneurial factor.

$$
\mathrm{NI}=(W i+C i+L i \pm P)
$$

Therefore, WFI is calculated by subtracting implicit costs for capital and land from NI.

\section{Results}

\section{Economic performance}

GFR shows heterogeneous magnitude, with an average of 89,775 euros (Table 2). An analysis of the average farm shows that agritourism generates a share of revenue equal to $46 \%$ of total GFR (considering that the part of agricultural production addressed to agritourism was not computed so as to avoid a double calculation problem).

By detailing each recreational activity provided to each total GFR, for four farms (2, 7, 9 and 11), such activities carry a weight of more than $75 \%$ of total GFR. Therefore, on these farms, the majority (if not all) of the agricultural production is sold through recreational activities. However, going into the details of agritourism revenue, Table 3 shows that the annual revenue per seat and bed is very low for most of the farms. 


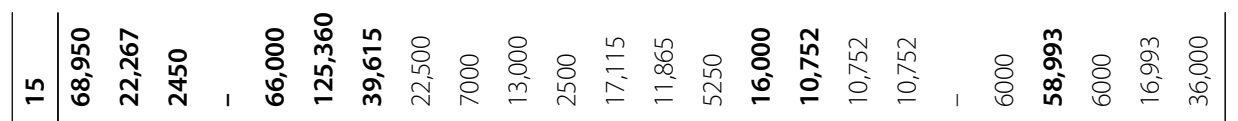

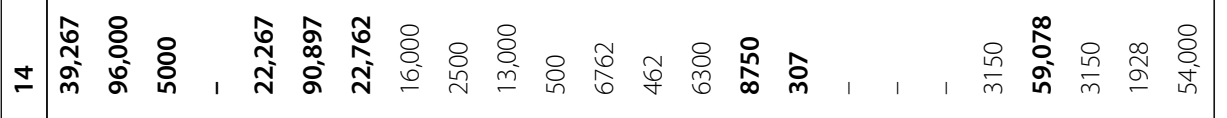

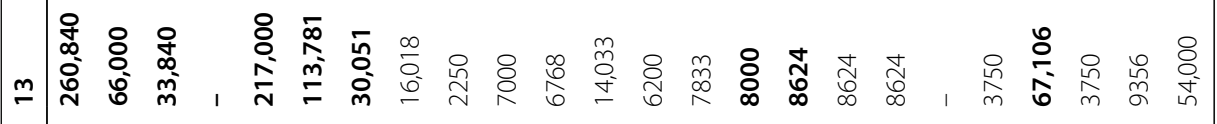

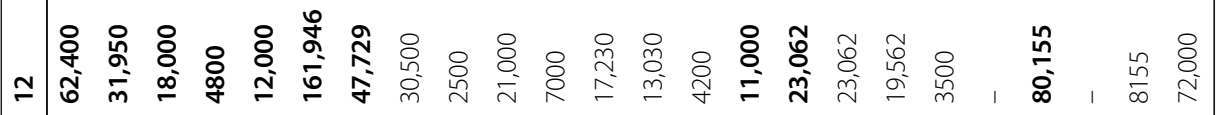

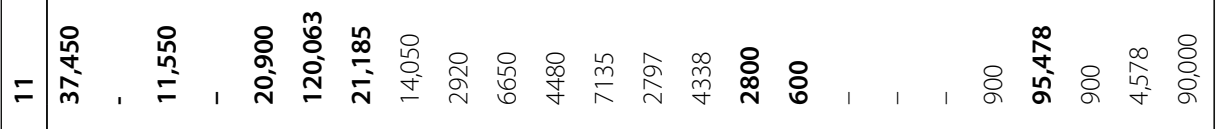

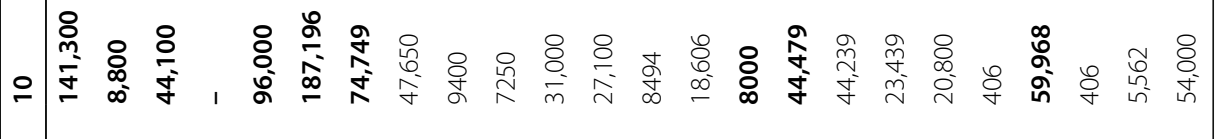

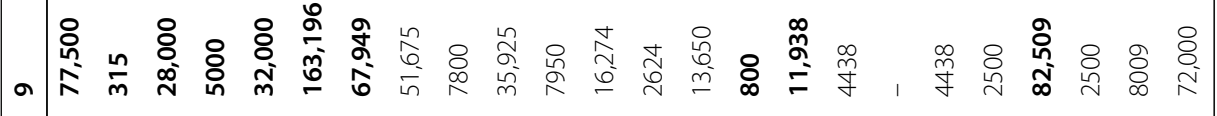

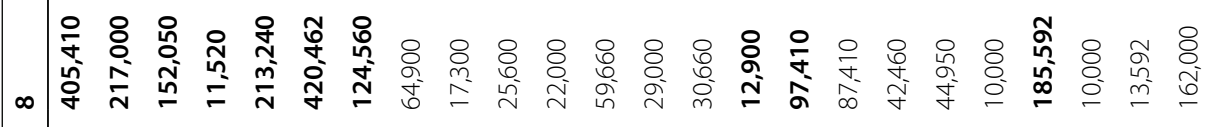

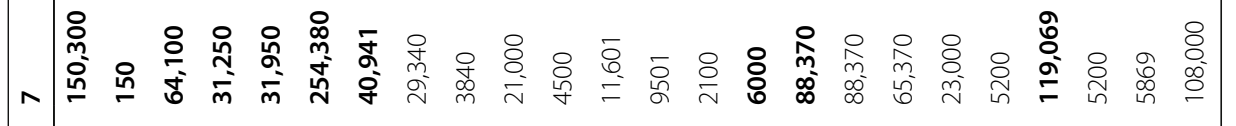

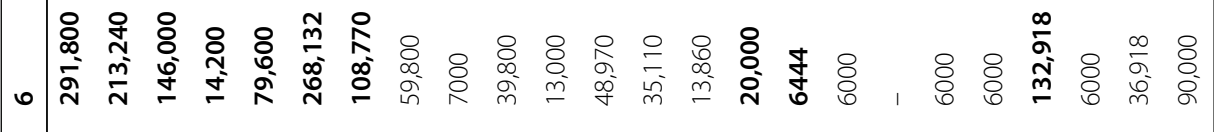

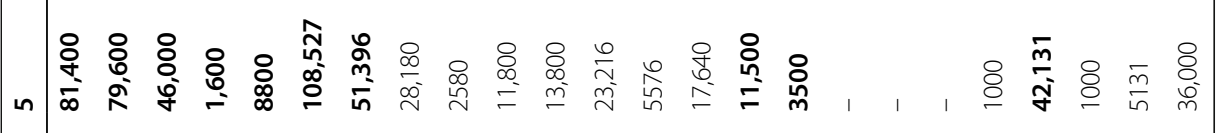

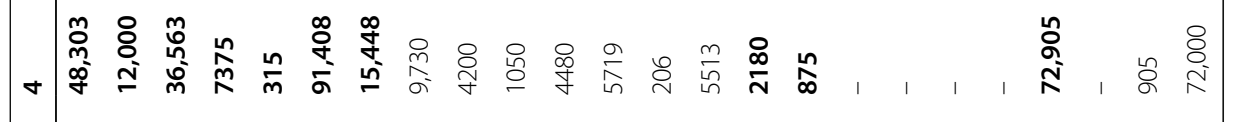

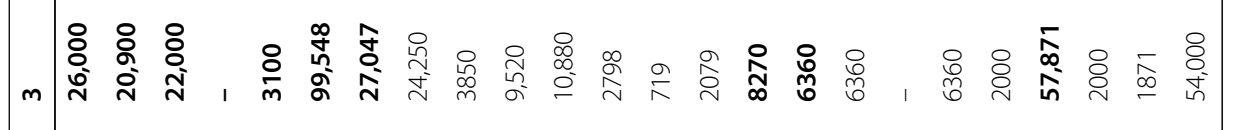

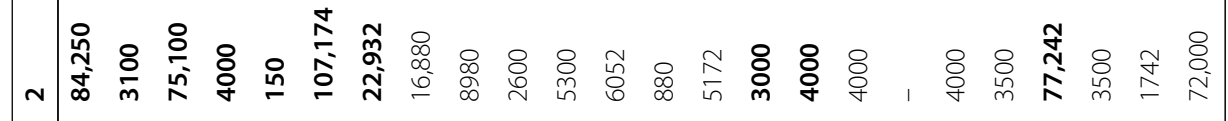

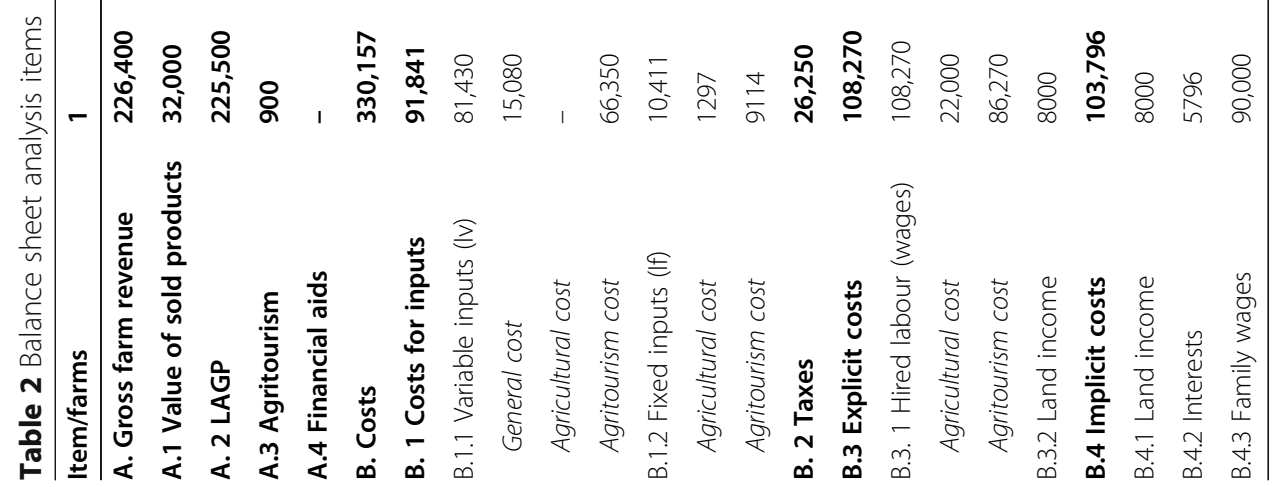




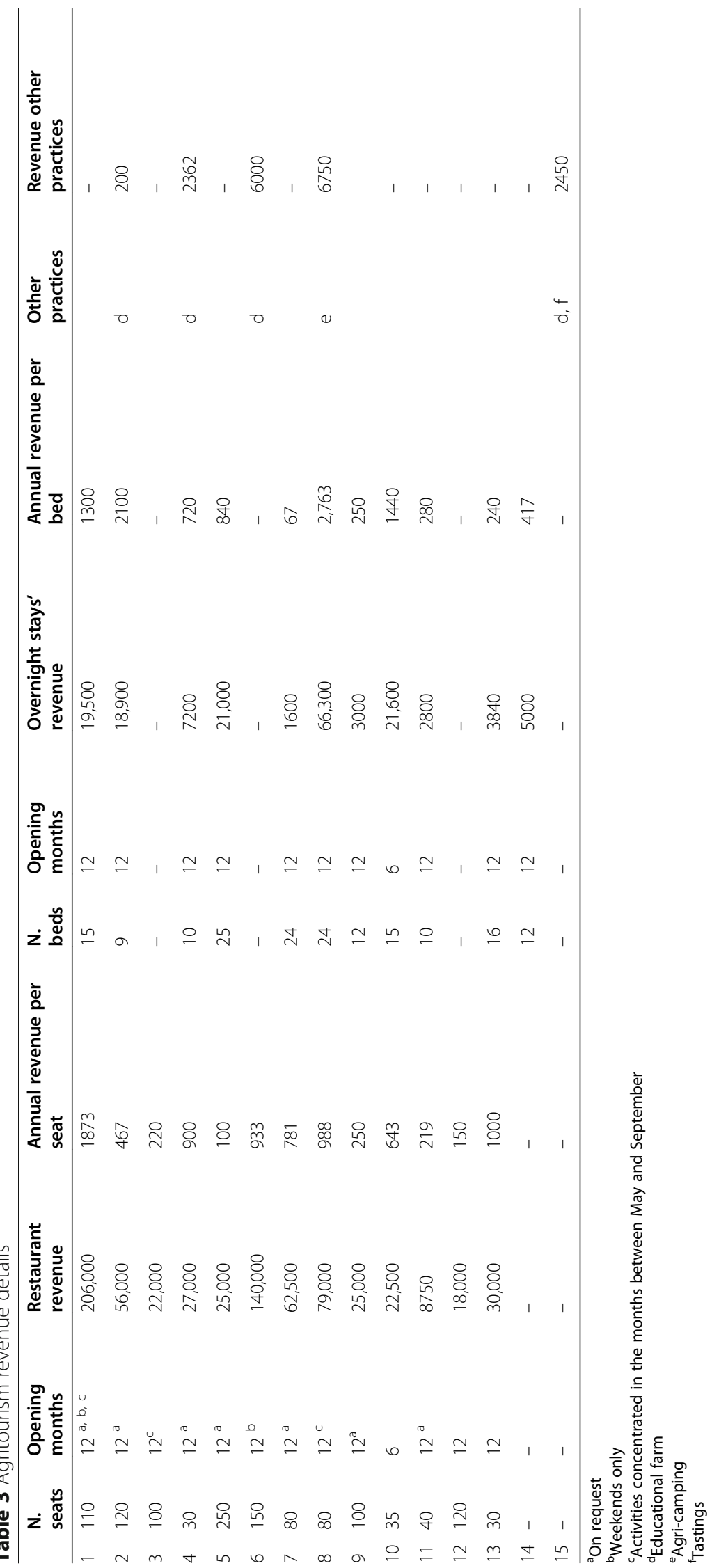


With reference to the costs, we found heterogeneous results among farms regarding the incidence of items and distribution of costs between agricultural and agritourism activities.

To be more precise, when we considered hired labour (wages), we found that on four farms, the work is done exclusively by the farmers. The data did not show a link between the intensity of hired labour and the share of revenue derived from agritourism on-farm activities on the whole. It must be pointed out, however, that the farm that reported the highest incidence of agritourism in terms of revenue (11; almost all GFR is composed of agritourism practices) shows the highest hired labour cost. This suggests that on this farm agritourism has increasing relevance and is actually in a more developed phase according to the Arnold and Staudacher model.

The balance sheet analysis findings show that one farm has a negative NFR (Table 4), meaning that the farm production process consumes more input than the income it produces. Furthermore, if the explicit costs of labour and land income are taken into account, the situation becomes worse, given that other two farms show negative values.

Taking into consideration the implicit cost as well, it appears that only 10 farms show positive WFI. This means that 33\% of farmers interviewed are not even able to at least partially reward their work at the market price level. Moreover, going into the WFI details, the findings show that few farms achieve a congruous level of WFI. Indeed, WFI appears positive but under 10,000 euros at five farms; therefore, considering that WFI involves both implicit wages and profits, it implies that income generated is far from adequate.

Finally, the estimation of implicit wages allows us to understand whether farm family work is adequately rewarded and whether the activity is eventually profitable (the positive difference between WFA and implicit wages). For this assessment, the basic salary of a permanent non-specialised worker was calculated based on the so called "local law salary tables"-normative tables that indicate a reference for salaries in agriculture and

Table 4 Results from balance sheet analysis

\begin{tabular}{|c|c|c|c|c|c|c|c|c|c|c|c|c|c|c|c|}
\hline Item/farms & 1 & 2 & 3 & 4 & 5 & 6 & 7 & 8 & 9 & 10 & 11 & 12 & 13 & 14 & 15 \\
\hline $\begin{array}{l}\text { Net farm } \\
\text { revenue } \\
\text { (NFR) }\end{array}$ & $\begin{array}{l}108 \\
309\end{array}$ & $\begin{array}{l}58 \\
318\end{array}$ & $\begin{array}{l}- \\
9317\end{array}$ & $\begin{array}{l}30 \\
675\end{array}$ & $\begin{array}{l}18 \\
504\end{array}$ & $\begin{array}{l}163, \\
030\end{array}$ & $\begin{array}{l}103 \\
359\end{array}$ & $\begin{array}{l}267, \\
950\end{array}$ & 8751 & $\begin{array}{l}58 \\
551\end{array}$ & $\begin{array}{l}13 \\
465\end{array}$ & 3671 & $\begin{array}{l}222, \\
789\end{array}$ & 7755 & $\begin{array}{l}13 \\
335\end{array}$ \\
\hline \multicolumn{16}{|l|}{$\begin{array}{l}\text { A - (B.1+ } \\
\text { B.2) }\end{array}$} \\
\hline $\begin{array}{l}\text { Net income } \\
\text { (NI) }\end{array}$ & 39 & $\begin{array}{l}54 \\
318\end{array}$ & $\begin{array}{l}- \\
15 \\
677\end{array}$ & $\begin{array}{l}29, \\
800\end{array}$ & $\begin{array}{l}15 \\
004\end{array}$ & $\begin{array}{l}156 \\
586\end{array}$ & $\begin{array}{l}14, \\
989\end{array}$ & $\begin{array}{l}170, \\
540\end{array}$ & $\begin{array}{l}- \\
3187\end{array}$ & $\begin{array}{l}14 \\
072\end{array}$ & $\begin{array}{l}12 \\
865\end{array}$ & $\begin{array}{l}- \\
19 \\
391\end{array}$ & $\begin{array}{l}214 \\
165\end{array}$ & 7448 & 2583 \\
\hline \multicolumn{16}{|l|}{$\begin{array}{l}\text { NFR - } \\
\text { (B.3) }\end{array}$} \\
\hline $\begin{array}{l}\text { Working } \\
\text { farm } \\
\text { income } \\
\text { (WFI) }\end{array}$ & $\begin{array}{l}- \\
13 \\
757\end{array}$ & $\begin{array}{l}49 \\
076\end{array}$ & $\begin{array}{l}- \\
19 \\
548\end{array}$ & $\begin{array}{l}28, \\
895\end{array}$ & 8873 & $\begin{array}{l}113, \\
668\end{array}$ & 3920 & $\begin{array}{l}146, \\
948\end{array}$ & $\begin{array}{l}- \\
13 \\
696\end{array}$ & 8104 & 7387 & $\begin{array}{l}- \\
27 \\
546\end{array}$ & $\begin{array}{l}201, \\
059\end{array}$ & 2370 & $\begin{array}{l}- \\
20 \\
410\end{array}$ \\
\hline \multicolumn{16}{|l|}{$\begin{array}{l}\mathrm{Nl}-(\mathrm{B} .4 .1 \\
+ \text { B.4.2) }\end{array}$} \\
\hline $\begin{array}{l}\text { Profit (or } \\
\text { loss) }\end{array}$ & $\begin{array}{r}- \\
103, \\
757\end{array}$ & $\begin{array}{l}- \\
22, \\
924\end{array}$ & $\begin{array}{l}- \\
73, \\
548\end{array}$ & $\begin{array}{l}- \\
43 \\
105\end{array}$ & $\begin{array}{l}-27 \\
127\end{array}$ & $\begin{array}{l}23 \\
668\end{array}$ & $\begin{array}{l}- \\
104 \\
080\end{array}$ & $\begin{array}{l}- \\
15 \\
052\end{array}$ & $\begin{array}{l}- \\
85 \\
696\end{array}$ & $\begin{array}{l}-45 \\
896\end{array}$ & $\begin{array}{l}-82 \\
613\end{array}$ & $\begin{array}{l}- \\
99 \\
546\end{array}$ & $\begin{array}{l}147 \\
059\end{array}$ & $\begin{array}{l}- \\
51 \\
630\end{array}$ & $\begin{array}{l}- \\
56 \\
410\end{array}$ \\
\hline$(A-B)$ & & & & & & & & & & & & & & & \\
\hline
\end{tabular}


that they are used for setting the contract salary-, which indicate 1200 euros per month (i.e. approximately 1500 euros including social security and sickness benefit at market price levels). Such value was applied for each family member based on the amount of work they perform on the farm. Consequently, only two farms (6 and 13) fully reward family work and show a positive profit.

\section{Remarks from economic indicators analysis}

Some economic indicators were calculated to give more detailed information about agritourism productivity and profitability.

The first indicator is the GFR per hectare, which gives information about land productivity. Using the utilised agricultural area (UAA) for measuring used land, we calculated productivity $\left(\mathrm{L}_{\mathrm{a}} \mathrm{P}\right)$ as follows:

$$
\mathrm{L}_{\mathrm{a}} \mathrm{P}=\mathrm{GFR} / \mathrm{UAA}
$$

We found that diversity in GFR cannot be precisely attributed to land productivity (Table 5). Indeed, it appears that there is not a strong relationship between GFR and productivity, although the notable point is that the two farms with the lowest UAA (4 and 10) are those with the largest $\mathrm{L}_{\mathrm{a}} \mathrm{P}$. Specifically, farm 10 shows land productivity sensitively higher than the average.

However, considering the small size of the observed sample, we applied the nonparametric Spearman's rank correlation test to verify a possible correlation between $\mathrm{L}_{\mathrm{a}} \mathrm{P}$ and farm revenue. Results reported in Table 6 show that the correlation is weak and not statistically significant (for $\alpha=0.10$ ). At the same time, no significant correlation was found between $\mathrm{L}_{\mathrm{a}} \mathrm{P}$ and WFI, implying that land is not a factor that significantly affects farmers' incomes.

A second indicator concerns labour productivity. Farm diversification can lead to positive effects for family-run farms in creating value and, as a consequence, increasing economic productivity, with special reference to labour productivity. Furthermore, we expect to save costs (e.g., transaction costs) and increase labour productivity due to recreational services and other related activities downstream of agriculture.

A previous study found that labour tends to be less efficient, in terms of single-input efficiency estimated, than most of the inputs in agritourism farms, especially in Sardinia (Arru, 2019). This would occur because the weight of labour involved in recreational activities does not exceed the labour spent in agricultural practices according to the Italian regulations on agritourism. This constraint implies that farmers are not fully able to divide labour based on their own needs, with probable consequences in terms of efficiency (inefficient allocation of the input) and productivity.

Furthermore, we observed extensive employment of family work, often for both agricultural and recreational activities. This can represent a source of inefficiency due to difficulty in achieving rational work allocation.

In the light of these considerations, we calculated the labour productivity $\left(\mathrm{L}_{\mathrm{b}} \mathrm{P}\right)$ for each farm, as follows:

$$
\mathrm{L}_{\mathrm{b}} \mathrm{P}=\mathrm{GFR} / \mathrm{WU}
$$

where WU represents working unit (WU $=1800$ working hours according to EU indications). 


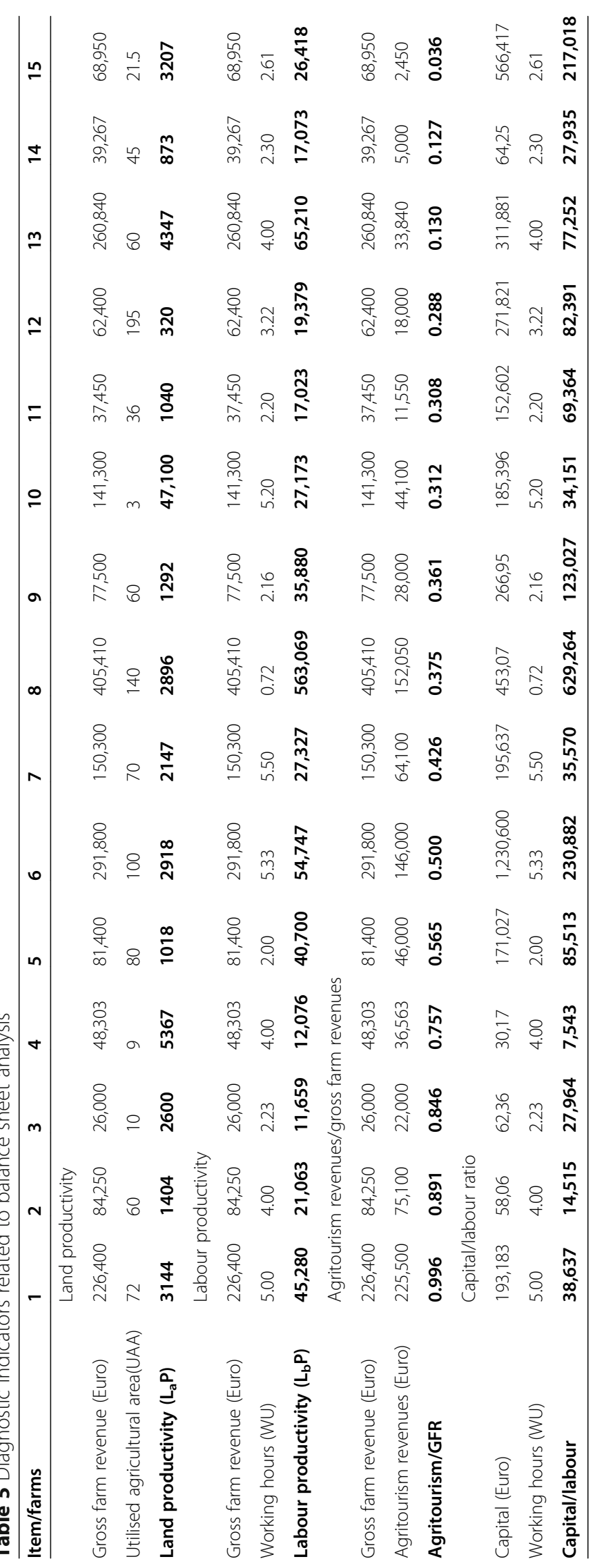


Table 6 Spearman's rank correlations among diagnostic variables and some balance sheet analysis findings

\begin{tabular}{llll}
\hline Variable 1 & Variable 2 & Coefficient & p value \\
\hline Land productivity $\left(\mathrm{L}_{\mathrm{a}} \mathrm{P}\right)$ & Gross farm revenues $(\mathrm{GFR})$ & 0.396 & 0.138 \\
Land productivity $\left(\mathrm{L}_{\mathrm{a}} \mathrm{P}\right)$ & Working farm income $(\mathrm{WFI})$ & 0.332 & 0.214 \\
Labour productivity $\left(\mathrm{L}_{\mathrm{b}} \mathrm{P}\right)$ & Gross farm revenues $(\mathrm{GFR})$ & 0.921 & 0.001 \\
Labour productivity $\left(\mathrm{L}_{\mathrm{b}} \mathrm{P}\right)$ & Working farm income $(\mathrm{WFI})$ & 0.485 & 0.069 \\
Agritourism revenues/GFR & Gross farm revenues $(\mathrm{GFR})$ & 0.157 & 0.556 \\
Agritourism revenues/GFR & Working farm income $(\mathrm{WFI})$ & 0.164 & 0.539 \\
Agritourism revenues/GFR & Labour productivity $\left(\mathrm{L}_{\mathrm{b}} \mathrm{P}\right)$ & 0.010 & 0.968 \\
Capital/labour ratio & Gross farm revenues $(\mathrm{GFR})$ & 0.371 & 0.164 \\
Capital/labour ratio & Working farm income $(\mathrm{WFI})$ & -0.032 & 0.904 \\
Capital/labour ratio & Agritourism revenues/GFR & -0.325 & 0.224 \\
$\mathrm{~N}=15$ & & & \\
\hline
\end{tabular}

Table 5 shows the $\mathrm{L}_{\mathrm{b}}$ Ps calculated. A sensitive degree of heterogeneity was found among the calculated $\mathrm{L}_{\mathrm{b}} \mathrm{Ps}$ and a significant relationship between revenue and productivity was estimated (Table 6). In other words, the most productive agritourism farms (concerning labour) are most probably the same farms characterised by the highest revenue. This suggests that labour significantly affects production, and as a consequence, rational and efficient use of labour would improve the ability to increase the farm's gross revenue. Furthermore, efficient use of labour and the consequent effects on production would generate positive outcomes in profitability. Indeed, both profitable farms (6 and 13) show higher labour productivity than the sample even if the most productive farm (8) shows no profitable activity. Any evident relationship was found between labour productivity and the stage in which lie the farms according to the Arnold and Staudacher (1981).

The relationship between labour productivity and working farm income is weaker than the one mentioned above (Table 6), but it is still significant. Obviously, it depends on the weight of familial and hired work, which differs among the observed farms.

A third diagnostic indicator is the ratio of agritourism revenue to total GFR (Table 5). As reported above, this ratio is sensitively variable, mainly depending on two factors: the phase achieved by the agritourism farm in its development process (some farms are at the beginning stage of agritourism diversification) and the need to respect the normative prevalence constraint. According to these factors, the calculated ratio would reflect different agritourism models. Indeed, a significant correlation was estimated between this ratio and the GFR and WFI. This suggests that the weight of agritourism revenue with respect to the farm's gross revenue can be an indicator of the development phase the agritourism business is in according to the Arnold and Staudacher framework, but cannot itself be considered as an efficiency indicator, i.e. as a proxy for the farmer's ability to be productive and remunerative. However, findings reported in Table 5 put on evidence as the farms that lie in third development stage show, on average, a greater value in this indicator (0.895) than the others $(0.497$ and 0.242 for that operating at phase 2 and 1 , respectively).

On the other hand, we also estimated the correlation between this ratio and the $\mathrm{L}_{\mathrm{b}} \mathrm{P}$ indicator. The results suggest that a significant relationship exists, and it implies that 
the sources of farm value, agritourism services or agriculture stricto sensu, are not generally related to labour productivity. This means that labour productivity affects farm revenue but is not prevalently oriented to a specific farm activity, at least so far.

The last indicator calculated is the ratio of capital invested to labour used, which would reflect the level of capital intensification at the observed agritourism farms. Capital was defined in terms of fixed capital (e.g., buildings, plants, machinery) and working capital.

The fourth indicator also shows heterogeneous values (Table 5), implying different degrees of capital intensification (or, vice versa, labour intensification) among the farms. The agritourism farm showing the highest ratio is number 8 , even if it is not profitable. At the same time, other farms (especially 6, 9, and 15) reveal a high ratio of capital for the labour involved, but capital intensity does not lead to their profitability, or at least to achieving a positive working farm income. This result would indicate overcapitalization of these farms and inefficiency in using capital.

The estimation of the relationship between this indicator and other variables would confirm farm overcapitalization. Indeed, a not significant correlation between capital intensification and GFR was found, probably depending on the fact that some farms have invested capital for agritourism services but this activity is not yet well developed. This can be underlined also considering the correlation between this indicator and the impact of agritourism practices on GFR. Even if not statistically significant, we found an inverse relationship, implying that the decision to move towards management with a higher rate of capital, probably due to replacing more of the business with agritourism, has not yet transformed into a shift in revenue towards agritourism.

Furthermore, any correlation between the value of this indicator and the development phase of the agritourist farms was found.

\section{Discussion and conclusion}

In 1975, the EU priority in the LFAs definition was the farm income level. In 2005, the focus of EU attention shifted to the natural handicaps suffered in the regions, preferring them as criteria to define LFAs for socio-economic consideration (Castel et al. 2011). Nowadays, the situation has not basically changed.

To deal with the exodus from farms located in LFAs, the abandonment of agricultural land, and the loss of biodiversity, rural cultural heritage and, in broad terms, the country's history and culture (Cooper et al. 2006), direct EU payments for farming represent pivotal income support for family farm businesses within LFAs (Takayama et al. 2019). However, they cannot lead to achieving the goal of maintaining the population in these areas if the farm families operating in such areas are not adequately paid for their work.

In this study, we examined the ability of farms in the LFA of Montiferru to reward family work by adopting diversification strategies through the establishment of agritourism.

First of all, the analysis focused on the diversity of revenue and the relative sources among farms. We found that such characteristics cannot be associated with specific business farm models (Broccardo et al. 2017) but are preferably linked to the ability of individual farms to use their resources and to differentiate the activity. We observed a sensitive heterogeneity among selected farms that allows us to assume that they operate 
in different development phases based on the theoretical model proposed by Arnold and Staudacher (1981). Some farms would be placed in the initial phase of development, e.g. few beds and no reduction in agriculture labour in favour of agritourism. The consequence is a lack of presence, which can lead to a deficit situation. This is because the Montiferru region is in the involvement stage of Butler's model (1980) and is attracting near-allocentric seasonal tourism, which, moving from the most renowned areas of Sardinia, asks for more adequate structures. Certainly, the level of seasonality "undermines business profitability and the capacity to reinvest and renew the infrastructure" (Pulina et al. 2006, p. 1014). Moreover, the seasonality issues affect also the other main activity. Arru et al. (2019) found that especially restaurant services are not fully utilised in agritourism in the Montiferru region-since these services are calibrated taking into account the highest summer tourist flow-making agritourism farms inefficient. However-even if it is a remote hypothesis-at the basis of low rate of efficiency in restaurant services might be the lack of adequate skills in agritourist farmers (e.g. depending on the development stage in which they lie). Farmers should provide a broader range of services and attractions to deseasonalise the business and thus supplement the income and boost employment (Pulina et al. 2006; Arru et al. 2019).

In this study, we found that capital intensification is not sensitively related to profitability, or at least the ability to increase the family income. These data could depend on the inefficient use of services, especially restaurants, as reported above, depending, on the one hand, on the seasonality of such activities (Parte-Esteban et al. 2015; Mhlanga 2018), and, on the other, by the fact that these farms are operating in the initial phase of development.

Another group of farms would be placed in the second phase of Arnold and Staudacher's model, showing an adequate balance between agriculture and tourism. On these farms, agriculture and tourism revenue are quite equal to each other and are often reinvested in agriculture.

The "prevalence constraint" in favour of agriculture would be respected in terms of revenue or use of labour (the labour used for agritourism cannot overcome that used for agriculture). The labour factor explains the critical role played by tourism activities in generating farm profit. Indeed, they are family businesses that took the multifunctionality path not only to increase their sources of income but also to make their farms autonomous with regard to the family's occupational needs (Cardillo and Cimino 2017). The data suggest that farm family members find job opportunities on the farms and that these chances increase with increased agritourism activity. On the other hand, a great prevalence of agritourism within agricultural practice can lead farms to inefficiency, especially in labour use, due to the need to ensure prevalence in agriculture work, and it can affect the ability to achieve satisfactory remuneration.

Indeed, the last group is composed of farms where agritourism is the main activity, and therefore they are in a phase characterised by the importance of diversification in the farm strategy. However, we found that this high specialization in agritourism is not correlated with the economic dimension of the farm, implying, among other things, that strategies highly devoted to diversification are also promoted by small farms even if their economic performance is generally unsatisfactory.

The labour productivity results are linked to production size. This implies that more efficient use of labour is one of the main tools for achieving a good level of economic 
production. Therefore, on these types of farms, it is important to balance three needs: rational labour allocation, and respect for the prevalence of agriculture practice in terms of labour involved and/or revenue achieved.

Another important point to consider concerns the ability of farms to generate congruous WFI. Only two companies are able to remunerate the work of family members equal to the minimum wage and, as a consequence, to be (more or less) profitable. Resuming all these arguments, we can conclude that, on the one hand, agritourism generates jobs for farm family members, but, on the other hand, this labour, which is defined in reference to the hourly labour cost established by the provincial rates, is not adequately remunerated or, in some instances, is not rewarded at all. Therefore, the choice to pursue a path of differentiation allowed these newly established farms located in LFAs to integrate the farm income, although it is not enough yet.

This result can be analysed through a double reading. The first interpretation considers the farmer incapable of valuing his work. As shown by previous studies on agritourism (Phelan and Sharpley 2011), although agritourism has become more established as a means to integrate farm income, this development path can be affected by the lack of key business competencies needed for success. This, in turn, impacts LFA development, and this lack of skill needs to be addressed through training courses to support agritourism farmers. In particular, on need programs that take into account the special relationship between the farmer and the farm that has to see as business (Vik and McElwee 2011). The farm understood as a firm (Tohidyan Far and RezaeiMoghaddam 2019) required a more market-orientation in order to survive (Phillipson et al. 2004; Meert et al. 2005; Jones et al. 2009), and farmers have to increase their managerial knowledge to respond to the growing demand for food and rural tourism demand adequately. Indeed, "the recognition of business opportunities and strategic planning are major requirements for farmers. Through this, farmers are able to find ways and strategies to create a profitable business" (Vik and McElwee 2011, p. 392).

The second interpretation arises from the fact that farmers and their families generally live on the farm and consume the products obtained from the activity, and often their first goal is to achieve socio-emotional well-being. Such forms of revenue are hardly summarised to a synthetic economic value that can be added to the NFR. Furthermore, the value they attach to lifestyle is never included in the balance sheet analysis.

If the farm's goal is to obtain the highest level of WFI, not all farms achieve it. However, the challenge must be not only to make the WFI positive, but also to generate a profit that allows farms to increase the range of possible strategic choices; to favour economic, social and environmental resilience; and to overcome the vulnerability of rural areas. The demand for recreational activities on farms has increased over the last decades and is expected to increase in the future (Barbieri et al. 2016). The development of agritourism allows farmers to capture new food tourists' demand (Hall et al. 2004) and increase the agricultural production that can be sold, raising farm income and encouraging farmers to seek new innovative strategic paths that increase their profit. More generally, given that food tourism is pivotal in regional tourism promotion, which, in turn, is a vital element of agricultural development (Hall 2003), agritourism in LFAs may be an appropriate response to farms' income problems. 
Moreover, a noteworthy fact that cannot be attributed to the case is that one of the two companies showing positive results is the only one connected to a path of enhancement of local products, the Malvasia di Bosa wine route. This route draws on the main products of the area in order to promote the territory, and with it the wineries and agritourism, as well as hotels and restaurants, through the different paths of landscape-environmental and cultural interest. Furthermore, four other companies belong to national associations, two to LAG, and one has joined a consortium aimed at protecting indigenous grape varieties and local specialties. These data show the potential benefit of including agritourism in food and wine routes, which provides a chance to show up for the increasing demand for food experiences.

Our analysis shows the potential of agritourism to be a valid tool to support farms in LFAs. However, when the strategic objective is to avoid farm families leaving these areas, their work must be given a fair return. The challenge is to ensure that these farmers, whether they want to stay in the market and develop an increasingly competitive tourism market, embrace the challenge of changing their goals and creating businesses that maximise profit. Wider and greater tourism supply, as well as greater business skills and adherence to food and wine routes, can be viable options for the future.

The main impact of this study lies in considering the role of working farm income in determining the achievement of farm goals. The analysis of overall economic farm profit (Deepashree 2013) including both explicit and implicit costs allowed us to evaluate the opportunity cost of a farmer and/or his family members working on the farm. Indeed, although the socio-emotional factors cannot be ignored, the study of LFAs cannot disregard the analysis of a farm's ability to pay for all the resources used in its activity. Farmers are called to transform their agritourism in terms of structures and mentality (Ciolac et al. 2019) inasmuch, although the achievement of long-term profitability may not be the firm's purpose, it is a condition for its continuity and growth (Brunelli and Carlo 2019), as well as to create new wealth and wellness for rural community.

A final remark comes from the need to increase the business skills of farmers and their family members as well as highlighting exposure opportunities in the channels that most attract food tourism demand.

With reference to policy issues, it is well accepted that agritourism integrates farm income, and conserves and creates value for rural area (Broccardo et al. 2017). Nevertheless, because cooperation and networking skills are pivotal prerequisites to realise business opportunities (Vik and McElwee 2011), business skill development programmes and the promotion of local operator networks are needed in order to avoid the depopulation of LFAs and care for the landscape. Several companies are in the first stage of Arnold and Staudacher (1981), and their structure is not adequate to respond properly to the growing food and rural tourism demand. However, due to the reasonable circumstance in which less profitable businesses have a lower chance to access to capital and vice versa, the state or local government authorities can make easier access to external financial resources, for example, developing programs that would financially support agritourism with their initial fixed costs. Although in the new Common Agricultural Policy (CAP) there is an "intervention group" aimed at supporting investments, tangible and/or intangible, which contribute to the achievement of the specific 
objectives of the PAC, the above purpose clashes with the 14.7\% reduction in the EAFR $\mathrm{D}$ fund allocation for Italy (European agricultural fund for rural development) for the 2021-2027 period. It should be noticed that the eighth key objectives of the future CAP "Vibrant Rural Areas" aimed at favour jobs and growth in rural areas has to deal with the peculiarity of farm entrepreneurs and the fact that "farmer are motivated by things other than financial reward" (Vik and McElwee 2011, p. 393). The European Union must invest in programs that push towards a change in the mentality of the farmers, who have to look not only at socio-emotional well-being and accounting profit, but also overall economic profit. Only the latter can be a valid measure of farm efficiency in achieving the goals, i.e. farm families being rewarded for their work, and obtaining a profit that makes the strategic choices for farm survival actually feasible.

In addition, in light of the other key objectives of CAP 2021-2027 inspired by the environmental, social and economic dimensions of sustainability, and the role of recreational activities in sustainability promotion, and good agricultural practices encouragement, with a positive impact on farms, households and rural territory development (Tew and Barbieri 2012; Mastronardi et al. 2015; Flanigan et al. 2015), it is particularly important that policy-makers promote a shift of perspective of farmers perhaps too focused on subjective success factors (Mäkinen et al. 2009) towards a new agritourism business model that aims to increase firm's profitability-that is in line with "with economic and non-economic benefits for society and the local community" (Broccardo et al. 2017, p. 2). This represents a viable option for overcoming the lags of farm income behind the rest of the economy. Finally, in light of the advantages offered by the network of local entrepreneurs and the "g" group of CAP "cooperation" interventions, the activity of the States should be directed towards the development of these activities in the LFAs areas.

In terms of academic implications, this study shows the need to expand research on LFAs in terms of analysing the elements that can contribute to maintaining the population in these areas, starting from the farms' overall economic profit. There are clear limitations to the case. First is the small sample size, although it covers nearly all agritourism in the area. Second, it relates to one specific Italian region. Clearly, further large-scale studies or comparative studies in other LFAs are needed, but the study provides a sound starting point.

\begin{abstract}
Abbreviations
Ce: Explicit cost related to the provision of capital (interests); Ci: Implicit cost related to the provision of capital (interests); GFR: Gross farm revenue; If: Cost for the depreciation charge on fixed technical inputs; Iv: Cost for the use of variable inputs; LAGP: Live animal gross profit margin; Le: Explicit cost related to the ownership of the land (land income); Li: Implicit cost related to the ownership of the land (land income); NFR: Net farm revenue; NI: Net income; P: Profit (or loss); Tx: Value of taxes paid; Vfi: Value of the livestock at the end of the $n$ year; Vii: Value of the livestock at the beginning of the $n$ year; $V p$ : Value of meat purchased in an $n$ year; Vs: Value of meat sold in an $n$ year; We: Explicit cost for remunerating work (wages); WFI: Working farm income; Wi: Implicit wage
\end{abstract}

Acknowledgements

Any person or institution needs to be acknowledged.

Authors' contributions

The study was jointly carried out and written by the authors. All authors read and approved the final manuscript.

Authors' information

BA and FM are junior and senior assistant professors, respectively, at the University of Sassari (Italy). RF and PP are full professors at the University of Sassari, Italy.

Funding

This research was carried out by the PROMETEA (PROmozione della Multifunzionalita dEl seTtorEAgro-turistico) granted by the INTERREG Marittimo-IT FR-Maritime EU Programme. 


\section{Availability of data and materials}

The datasets analysed during the current study are not publicly available due to confidentiality of personal data but are available in a restricted form from the corresponding authors on reasonable request.

\section{Declarations}

\section{Competing interests}

Each author discloses any actual or potential conflict of interest including any financial, personal, or other relationships with other people or organizations that could inappropriately influence, or be perceived to influence, their work. The funders had no role in the design of the study; in the collection, analyses, or interpretation of data; in the writing of the manuscript, or in the decision to publish the results.

Received: 21 December 2019 Revised: 25 March 2020 Accepted: 15 June 2021 Published online: 29 July 2021

\section{References}

Arnold K, Staudacher C (1981) Urlaub auf dem Bauernhof: eine empirische Untersuchung der Struktur und Entwicklung einer spezifischen Erholungsform und ihrer Auswirkungen auf die Land-und Forstwirtschaft in Niederösterreich. Hirt

Arroyo CG, Barbieri C, Rich SR (2013) Defining agritourism: a comparative study of stakeholders' perceptions in Missouri and North Carolina. Tour Manag 37:39-47. https://doi.org/10.1016/j.tourman.2012.12.007

Arru B, Furesi R, Madau FA, Pulina P (2019) Recreational services provision and farm diversification: a technical efficiency analysis on Italian agritourism. Agriculture 9(2):42. https://doi.org/10.3390/agriculture9020042

Atzori AS, Furesi R, Madau FA, Pulina P, Rassu SPG (2015) Sustainability of Dairy Sheep Production in Pasture Lands: a Case Study Approach to Integrate Economic and Environmental Perspectives. Rev Stud Sustainability 1: 117-134

Barbieri C, Xu S, Gil-Arroyo C, Rich SR (2016) Agritourism, Farm Visit, or ... ? A Branding Assessment for Recreation on Farms. J Travel Res 55(8):1094-1108. https://doi.org/10.1177/0047287515605930

Bateman D, Ray C (1994) Farm pluriactivity and rural policy: some evidence from Wales1. J Rural Stud 10(1):1-13. https://doi. org/10.1016/0743-0167(94)90002-7

Bellencin Meneghel G (1992) Agriturismo in Italia, Patron Editore, Granarolo

Bowler I (1992) 'Sustainable agriculture'as an alternative path of farm business development

Bredvold R, Skàlén P (2016) Lifestyle entrepreneurs and their identity construction: a study of the tourism industry. Tour Manag 56:96-105. https://doi.org/10.1016/j.tourman.2016.03.023

Broccardo L, Culasso F, Truant E (2017) Unlocking value creation using an agritourism business model. Sustainability 9(9): 1618. https://doi.org/10.3390/su9091618

Brunelli S, Di Carlo E (2019) Accountability, Ethics and Sustainability of Organizations: New Theories, Strategies and Tools for Survival and Growth, Springer Nature pp. 192

Butler RW (1980) The concept of a tourist area cycle of evolution: implications for management of resources. Can Geogr Géographe Can 24(1):5-12. https://doi.org/10.1111/j.1541-0064.1980.tb00970.x

Camanzi L, Arba E, Rota C, Zanasi C, Malorgio G (2018) A structural equation modeling analysis of relational governance and economic performance in agri-food supply chains: evidence from the dairy sheep industry in Sardinia (Italy). Agric Food Econ 6(1):4. https://doi.org/10.1186/s40100-018-0099-z

Cardillo C, Cimino O (2017) Aziende multifunzionali vs aziende convenzionali: un'analisi dell'agricoltura italiana attraverso i dati rica. Paper presented at the XXXVIII Conferenza italiana di scienze regionali, University of Cagliari, Cagliari, 20-22 June 2017

Castel JM, Mena Y, Ruiz FA, Camúñez-Ruiz J, Sánchez-Rodríguez M (2011) Changes occurring in dairy goat production systems in less favoured areas of Spain. Small Rumin Res 96(2-3):83-92. https://doi.org/10.1016/j.smallrumres.2011.01.002

Ciolac R, Adamov T, lancu T et al (2019) Agritourism-a sustainable development factor for improving the 'health'of rural settlements. Case Study Apuseni Mountains Area. Sustainability 11:1467

Cooper T, Baldock D, Rayment M, Kuhmonen T, Terluin I, Swales V, Poux X, Zakeossian D Farmer M (2006) An Evaluation of the Less Favoured Area Measure in the 25 Member States of the European Union. A report for DG Agriculture. Institute for European Environmental Policy, London pp 249

Council of the European Union (2013) Regulation (EU) No 1305/2013 of the European Parliament and of the Council of 17 December 2013 on support for rural development by the European Agricultural Fund for Rural Development (EAFRD) and repealing Council Regulation (EC) No 1698/2005

De Rosa M, McElwee G, Smith R (2019) Farm diversification strategies in response to rural policy: a case from rural Italy. Land Use Policy 81:291-301. https://doi.org/10.1016/j.landusepol.2018.11.006

Deepashree (2013) General Economics: For CA-CPT 2e - Paperback, Tata McGraw Hill Education Private Limited (2e edition). pp. 454

European Commission (2013) Family farming. In: Agric. Rural Dev. - Eur. Comm. https://ec.europa.eu/agriculture/family-fa rming_en. Accessed 13 Jun 2019

European Commission (2017) CAP Content indicators 2014-2020

Fagioli FF, Diotallevi F, Ciani A (2014) Strengthening the sustainability of rural areas: the role of rural tourism and agritourism. Riv Econ Agrar Rev Agric Econ 69:155-169

Fischer E, Qaim M (2012) Linking smallholders to markets: determinants and impacts of farmer collective action in Kenya. World Dev 40(6):1255-1268. https://doi.org/10.1016/j.worlddev.2011.11.018

Flanigan S, Blackstock K, Hunter C (2014) Agritourism from the perspective of providers and visitors: a typology-based study. Tour Manag 40:394-405. https://doi.org/10.1016/j.tourman.2013.07.004

Flanigan S, Blackstock K, Hunter C (2015) Generating public and private benefits through understanding what drives different types of agritourism. J Rural Stud 41:129-141. https://doi.org/10.1016/j.jurstud.2015.08.002

Furesi R, Madau FA, Pulina P (2013) Technical efficiency in the sheep dairy industry: an application on the Sardinian (Italy) sector. Agric Food Econ 1(1):4. https://doi.org/10.1186/2193-7532-1-4 
Gomez-Mejia LR, Cruz C, Berrone P, De Castro J (2011) The bind that ties: socioemotional wealth preservation in family firms. Acad Manag Ann 5(1):653-707. https://doi.org/10.5465/19416520.2011.593320

Hall CM, Mitchell R, Sharples L (2003) Consuming places: the role of food, wine and tourism in regional development. In: Hall CM, Sharples L, Mitchell R, Macionis N, Cambourne B, editors. Food Tourism Around The World. Development, management and markets. Routledge, pp, 25-59

Henke R, Povellato A, Vanni F (2014) Elementi di multifunzionalità nell'agricoltura italiana: una lettura dei dati del Censimento. QA Riv Dell'Associazione Rossi-Doria 1:101-133

Hall D, Roberts L, Mitchell M (2003) New Directions in Rural Tourism. Ashgate, Aldershot

Ilbery BW (1991) Farm diversification as an adjustment strategy on the urban fringe of the West Midlands. J Rural Stud 7(3): 207-218. https://doi.org/10.1016/0743-0167(91)90085-7

Istat (2019) https:/www.istat.it/

Johnsen S (2004) The redefinition of family farming: agricultural restructuring and farm adjustment in Waihemo, New Zealand. J Rural Stud 20(4):419-432. https://doi.org/10.1016/j.jrurstud.2004.07.002

Jones D, Moreddu C, Kumagai T (2009) The role of agriculture and farm household diversification in the rural economy: Evidence and initial policy implications

Knowd I (2006) Tourism as a mechanism for farm survival. J Sustain Tour 14(1):24-42. https://doi.org/10.1080/ 09669580608668589

Liu S-Y, Yen C-Y, Tsai K-N, Lo W-S (2017) A conceptual framework for agri-food tourism as an eco-innovation strategy in small farms. Sustainability 9(10):1683. https://doi.org/10.3390/su9101683

Mäkinen H, Rantamäki-Lahtinen L, Ylätalo M, Vehkamäki S (2009) Measuring the success of Finnish family farms. Acta Agric Scand Sect C — Food Econ 6(3-4):185-196. https://doi.org/10.1080/16507541.2010.481900

Markelova H, Meinzen-Dick R, Hellin J, Dohrn S (2009) Collective action for smallholder market access. Food Policy 34(1):1-7. https://doi.org/10.1016/j.foodpol.2008.10.001

Marsden TK, Munton R, Whatmore S, Little J (1989) Strategies for coping in capitalist agriculture: an examination of the responses of farm families in British agriculture. Geoforum 20(1):1-14. https://doi.org/10.1016/0016-7185(89)90012-2

Mastronardi L, Giaccio V, Giannelli A, Scardera A (2015) Is agritourism eco-friendly? A comparison between agritourisms and other farms in Italy using farm accountancy data network dataset. SpringerPlus 4(1):590. https://doi.org/10.1186/s40064-015-1353-4

McGehee NG (2007) An agritourism systems model: a Weberian perspective. I Sustain Tour 15(2):111-124. https://doi.org/10.2167/jost634.0

Meert H, Van Huylenbroeck G, Vernimmen T et al (2005) Farm household survival strategies and diversification on marginal farms. J Rural Stud 21(1):81-97. https://doi.org/10.1016/j.jurstud.2004.08.007

Mhlanga O (2018) Factors impacting restaurant efficiency: A data envelopment analysis. Tour Rev, 73:82-93

Nickerson NP, Black RJ, McCool SF (2001) Agritourism: motivations behind farm/ranch business diversification. J Travel Res 40(1):19-26. https://doi.org/10.1177/004728750104000104

Parte-Esteban L, Alberca-Oliver P (2015) Determinants of technical efficiency in the Spanish hotel industry: Regional and corporate performance factors. Curr Issues Tour, 18:391-411

Petrovic MD, Bjeljac Z, Vuiko A (2016) Analysis of the life cycle of an agritourism destination - a theoretical approach. Agricultural Bulletin of Stavropol Region 4(2):77-81

Phelan C, Sharpley R (2011) Exploring Agritourism Entrepreneurship in the UK. Tour Plan Dev 8(2):121-136. https://doi.org/1 $0.1080 / 21568316.2011 .573912$

Phillip S, Hunter C, Blackstock K (2010) A typology for defining agritourism. Tour Manag 31(6):754-758. https://doi.org/10.101 6/j.tourman.2009.08.001

Phillipson J, Gorton M, Raley M, Moxey A (2004) Treating farms as firms? The evolution of farm business support from productionist to entrepreneurial models. Environ Plan C Gov Policy 22(1):31-54. https://doi.org/10.1068/C0238

Plog SC (1974) Why destination areas rise and fall in popularity. Cornell Hotel Restaur Adm Q 14(4):55-58. https://doi.org/1 $0.1177 / 001088047401400409$

Pulina M, Dettori DG, Paba A (2006) Life cycle of agrotouristic firms in Sardinia. Tour Manag 27(5):1006-1016. https://doi.org/1 0.1016/j.tourman.2005.10.023

Schilling BJ, Attavanich W, Jin Y (2014) Does Agritourism Enhance Farm Profitability? J Agricult Resour Econ 39(1):69-87

Schilling BJ, Sullivan KP, Komar SJ (2016) Examining the economic benefits of agritourism: The case of New Jersey. J Agric Food Syst Community Dev 3:199-214

Serpieri A (1950) Istituzioni di economia agraria. Bologna, Edizioni Agricole

Stotten R, Maurer M, Herrmann H, Schermer M (2019) Different forms of accommodation in agritourism: the role of decoupled farmer-based accommodation in the Ötztal Valley (Austria). Sustainability 11(10):2841. https://doi.org/10.3390/su1 1102841

Streifeneder T (2016) Agriculture first: assessing European policies and scientific typologies to define authentic agritourism and differentiate it from countryside tourism. Tour Manag Perspect 20:251-264. https://doi.org/10.1016/j.tmp.2016.10.003

Sznajder M, Przezbórska L, Scrimgeour F (2009) Agritourism pillars. Cabi. https://doi.org/10.1079/9781845934828.0000

Takayama T, Hashizume N, Nakatani T (2020) Impact of direct payments on agricultural land use in less-favoured areas: evidence from Japan. Eur Rev Agricult Econ, 47(1):157-177

Tew C, Barbieri C (2012) The perceived benefits of agritourism: the provider's perspective. Tour Manag 33(1):215-224. https:// doi.org/10.1016/j.tourman.2011.02.005

Toader M, Roman GV (2015) Family farming - examples for rural communities development. Agric Agric Sci Procedia 6:8994. https://doi.org/10.1016/j.aaspro.2015.08.043

Tohidyan Far S, Rezaei-Moghaddam K (2019) Multifunctional agriculture: an approach for entrepreneurship development of agricultural sector. J Glob Entrep Res 9(1):23. https://doi.org/10.1186/s40497-019-0148-4

Vik J, McElwee G (2011) Diversification and the entrepreneurial motivations of farmers in Norway. J Small Bus Manag 49(3): 390-410. https://doi.org/10.1111/j.1540-627X.2011.00327.x

Vogt L (2013) The economic side of agrotourism: business performance and competitive factors. Econ Agro-Aliment 3:77-102

\section{Publisher's Note}

Springer Nature remains neutral with regard to jurisdictional claims in published maps and institutional affiliations. 